Ensaio Pesquisa em Educação em Ciências, Vol. 2, No 1 (2000)

\title{
Estruturas para avaliação de tecnologia de aprendizagem multimídia: lições aprendidas e futuras direções
}

Denise whitelock

\section{Resumo}

A avaliação é um processo necessário no desenvolvimento de qualquer novo currículo. Entretanto, quando a tecnologia também está envolvida, o processo se torna ainda mais complexo. Este artigo defende metas claras de pesquisa e estruturas integradas para avaliação multimídia. Ele sugere uma possível via pelo campo minado da avaliação com algumas sugestões práticas sobre o planejamento de um estudo sobre avaliação. Materiais multimídia para aprendizagem tornam-se alvos interessantes para avaliação por atingirem como possíveis ambientes de teste para atuais teorias de aprendizagem. Essa área também é frequentemente negligenciada nos estudos recentes sobre avaliação. 